\title{
PENGEMBANGAN MEDIA PEMBELAJARAN AKUNTANSI BERBASIS WEB BLOG UNTUK MENINGKATKAN MOTIVASI BELAJAR
}

\section{THE DEVELOPMENT OF WEB-BASED ACCOUNTING LEARNING MEDIA BLOGS FOR INCREASING LEARNING MOTIVATION}

\author{
Oleh: \\ Shabrina Irmayanti \\ Pendidikan Akuntansi Universitas Negeri Yogyakarta \\ shabrina.irma@yahoo.co.id \\ Mahendra Adhi Nugroho \\ Staf Pengajar Jurusan P. Akuntansi Universitas Negeri Yogyakarta
}

\begin{abstract}
Abstrak
Penelitian ini bertujuan untuk mengembangkan Media Pembelajaran Akuntansi Berbasis Web Blog bagi siswa kelas XI Akuntansi 4 SMK YPKK 2 Sleman; mengetahui kelayakan Media Pembelajaran Akuntansi Berbasis Web Blog berdasarkan penilaian ahli materi, ahli media, guru Akuntansi, dan siswa, serta mengetahui peningkatan motivasi belajar. Penelitian ini merupakan penelitian pengembangan (R\&D) model pengembangan ADDIE. Teknik pengumpulan data melalui angket. Hasil penelitian yaitu berdasarkan penilaian: 1) Ahli Materi diperoleh rata-rata skor 3,68 termasuk kategori Sangat Baik, 2) Ahli Media diperoleh rata-rata skor 2,97 termasuk kategori Baik, dan 3) Guru Akuntansi diperoleh rata-rata skor 3,7 termasuk dalam kategori Sangat Baik. Penilaian kelayakan oleh siswa memperoleh rata-rata skor 3,4 termasuk kategori Sangat Baik. Peningkatan motivasi belajar sebesar 7,14\% dari 71,78\% menjadi 78,92\%. Kata Kunci: Media Pembelajaran Akuntansi, Web Blog, Motivasi Belajar, Perusahaan Dagang, ADDIE.
\end{abstract}

\section{Abstract}

This research aims to develop a Web-based Accounting Learning Media Blog for students of Class XI Accounting 4 SMK YPKK 2 Sleman; find out the feasibility of Web-based Accounting Learning Media Blog based on expert assessment material, media experts, teachers, and students; as well as knowing the increase in student learning motivation. This research is Research and Development $(R \& D)$ adapted from ADDIE model of development. Data collection techniques in the research of this development through the questionnaire and the questionnaire analyzed in qualitative and quantitative descriptive. The results: 1) Material expert obtained an average score 3.68 which included in very good, 2) Media experts obtained an average score 2.97 which included in the good, and 3) Accounting Teachers earned an average score of 3.7 which included in the category of very good. Feasibility assessment by the end of the test the students gained an average score 3.4 which includes the category of very good. Based on the analysis of the learning.Motivation increase of 7,14\% from $71,78 \%$ to $78,92 \%$.

Keywords: Media Learning Accounting, Web Blog, Learning Motivation, The Company Trademark, ADDIE. 


\section{PENDAHULUAN}

Pendidikan merupakan suatu hal yang penting dalam peradaban manusia. Melalui pendidikan, manusia dapat mengembangkan segala sumber daya yang dimiliki. Pendidikan juga turut berpengaruh terhadap perkembangan ilmu pengetahuan dan teknologi yang secara langsung mempengaruhi proses pembelajaran dan pencapaiannya dalam memotivasi peserta didik.

Menurut UU No. 20 Tahun 2003 seperti yang dikutip oleh Wina Sanjaya (2011: 2) tentang sistem pendidikan nasional menyatakan bahwa pendidikan adalah usaha sadar dan terencana untuk mewujudkan suasana belajar dan proses pembelajaran agar peserta didik secara aktif mengembangkan potensi dirinya untuk memiliki kekuatan spiritual keagamaan, pengendalian diri, kepribadian, kecerdasan, akhlak mulia, serta keterampilan yang diperlukan dirinya dan masyarakat

Keberhasilan dalam proses belajar mengajar tidak dapat terlepas dari peran guru, metode, serta media pembelajaran yang digunakan untuk menumbuhkan motivasi dan semangat belajar para siswa. Salah satu permasalahan pendidikan yang menjadi prioritas untuk segera dicari pemecahannya adalah masalah menurunnya motivasi belajar peserta didik dalam proses pembelajaran. Dari berbagai kondisi dan potensi yang ada, upaya yang dapat dilakukan adalah meningkatkan motivasi belajar yang berorientasi pada peserta didik dan memfasilitasi pembelajaran agar tujuan pendidikan yang telah ditentukan dapat tercapai secara optimal.

Penggunaan metode ceramah atau yang biasa disebut dengan metode pembelajaran konvensional dalam pembelajaran akuntansi sebenarnya bukan sebuah permasalahan, tetapi apabila metode ini digunakan terus menerus tanpa menggunakan variasi dalam pembelajaran misalnya penggunaan media untuk membantu proses belajar mengajar maka dapat memicu permasalahan lain. Permasalahan tersebut yaitu menurunnya motivasi belajar peserta didik dalam mengikuti proses belajar mengajar di kelas. Peserta didik tidak termotivasi untuk belajar serta kurang aktif dalam pembelajaran yang akan mengakibatkan proses pembelajaran tidak dapat berjalan secara optimal. Guru pada umumnya belum memanfaatkan media pembelajaran yang berada di sekolah melalui fasilitasfasilitas yang disediakan.

Penggunaan media pembelajaran, dapat menjadi salah satu inovasi untuk peserta didik dalam memahami setiap detail materi pelajaran sehingga mereka termotivasi untuk selalu mengikuti proses pembelajaran tanpa mengalami kejenuhan. Disisi lain, semakin berkembangnya tekonologi informasi di era globalisasi tentu semakin besar pula pengaruhnya terhadap pendidikan. Salah satunya yaitu inovasi dalam penggunaan media untuk mendukung proses pembelajaran.

Penggunaan media pembelajaran merupakan salah satu faktor eksternal yang mendukung keberhasilan dalam belajar. Guru dapat memilih media pembelajaran yang sesuai dan efisien untuk mencapai tujuan pendidikan. Penggunaan media pembelajaran yang tepat, dapat mendorong motivasi belajar siswa.

Penggunaan media dalam proses belajar mengajar tentu memiliki fungsi sebagai alat bantu mengajar yang dapat digunakan oleh guru untuk menyampaikan materi pelajaran kepada peserta didik. Salah satu alternatif pemilihan media yang dapat digunakan dalam mendukung proses pembelajaran untuk meningkatkan motivasi belajar siswa adalah penggunaan web blog. Media web blog merupakan salah satu referensi acuan yang memberikan sumbangan materi bagi pembelajaran untuk para peserta didik 
yang disesuaikan dengan materi ajar di sekolah.

Peserta didik terkadang mengalami kendala seperti tempat atau lokasi belajar dan waktu belajar. Kendala tersebut dapat diatasi dengan memanfaatkan layanan internet yang akan memberikan keleluasaan bagi peserta didik untuk mendapatkan sumber materi ajar di manapun dan kapanpun. Perkembangan jaringan internet tersebut kemudian berkembang menjadi sebuah layanan penyimpanan yang bisa memuat data dan bisa dipublikasikan kepada umum. Jenis layanan ini awalnya berupa web-page yang bersifat komersial, namun pada masa sekarang sudah banyak penyedia layanan web-page yang tidak komersial. Salah satu layanan yang sering digunakan adalah web blog yang sering dikenal dengan blog. Blog adalah salah satu media yang bisa digunakan sebagai media pembelajaran yang dapat diperoleh kapan saja dan mudah dibuat. Layanan ini menyediakan ruang untuk menyimpan data secara gratis. Contoh penyedia layanan web blog secara gratis ini antaralain wordpress dan blogger.

Saat ini belum banyak penggunaan web blog yang digunakan sebagai media pembelajaran. Media ini mempunyai banyak keunggulan dibandingkan media lain, diantaranya yaitu kemudahan dalam kegunaannya serta biaya cukup terjangkau. Melalui media web blog maka pembelajaran akan lebih menyenangkan karena tidak harus terpaku dengan metode ceramah yang biasanya digunakan oleh guru dalam menerangkan materi di kelas.

Dari hasil observasi yang dilakukan oleh peneliti selama melaksanakan kegiatan Praktik Pengalaman Lapangan (PPL) di kelas XI Akuntansi 4 SMK YPKK 2 Sleman, pembelajaran akuntansi lebih banyak dilakukan di dalam kelas dimana guru menggunakan metode pembelajaran yang pada umumnya diterapkan yaitu melalui ceramah. Setelah guru menjelaskan materi melalui ceramah, kemudian guru memberikan penugasan kepada siswa dan begitu seterusnya.

Disisi lain, pembelajaran sudah dibantu dengan lembar kerjas siswa (LKS) yang dikerjakan oleh siswa di dalam kelas. Selama empat jam pelajaran akuntansi, siswa berada di dalam kelas kecuali untuk mata pelajaran berupa praktik-praktik akuntansi menggunakan laboratorium komputer. Selama empat jam itulah, motivasi siswa terpantau tidak stabil. Untuk jam pertama dan kedua, siswa nampak memperhatikan dan masih termotivasi untuk mengikuti pembelajaran, namun memasuki jam ketiga dan keempat, motivasi siswa mulai menurun. Hal tersebut nampak dari beberapa siswa yang tertidur di kelas, tidak memperhatikan penjelasan guru dan tidak antusias dalam mengikuti proses pembelajaran.

Apabila dalam pelaksanaan pembelajaran guru menggunakan alternatif pembelajaran berupa media seperti web $b l o g$, tentu hal tersebut sangat memberikan nilai positif untuk siswa. Di SMK YPKK 2 Sleman itu sendiri, pembelajaran menggunakan media sangat mungkin untuk dilaksanakan. Hal ini ditunjukkan dengan tersedianya sarana dan prasarana yang mendukung yaitu berupa Laboratorium Komputer, tersedianya jaringan wifi dan tersedianya LCD di setiap kelas. Oleh sebab itu maka pembelajaran akuntansi dengan mengembangkan media pembelajaran berupa web blog sangat mungkin untuk dilaksanakan di SMK YPKK 2 Sleman.

Berdasarkan uraian di atas, dapat disimpulkan bahwa perlu dilakukan upaya untuk mendorong motivasi siswa melalui pengembangan suatu media pembelajaran. Melihat kenyataan tersebut penulis bermaksud mengadakan penelitian dengan judul "Pengembangan Media Pembelajaran Akuntansi Berbasis Web Blog untuk Meningkatkan Motivasi Belajar Siswa Kelas XI Akuntansi 4 SMK YPKK 2 Sleman Tahun Ajaran 2015/2016". 


\section{METODE PENELITIAN Jenis Penelitian}

Penelitian ini merupakan jenis penelitian berupa penelitian dan pengembangan (Research and Development) yang diadaptasi dari model pengembangan ADDIE (Endang Mulyatiningsih. 2013:200)

\section{Waktu dan Tempat Penelitian}

Penelitian ini dilaksanakan di kelas XI Akuntansi 4 SMK YPKK 2 Sleman. Penelitian yang dilakukan meliputi tahap persiapan pada bulan November sampai Desember 2015. Pelaksanaan bulan Januari 2016.

\section{Target/Subjek Penelitian}

Subjek uji coba adalah satu orang ahli materi yaitu Ibu RR. Indah Mustikawati, S.E.Akt.,M.Si., satu orang ahli media yaitu Bapak Estu Miyarso, M.Pd., praktisi pembelajaran yaitu guru Akuntansi SMK YPKK 2 Sleman dan 21 siswa kelas XI Akuntansi 4 SMK YPKK 2 Sleman. Objek penelitian adalah motivasi belajar.

\section{Prosedur}

Prosedur penelitian ini mengadaptasi model pengembangan ADDIE, yang terdiri dari lima tahapan yang meliputi tahap analisis (analysis), tahap desain (design), tahap pengembangan (development), tahap implementasi (implementation), dan tahap evaluasi (evaluation).

\section{Teknik Pengumpulan Data dan Instrumen Penelitian}

Penelitian ini menggunakan teknik pengumpulan data berupa angket. Instrumen penelitian angket diisi oleh ahli materi, ahli media, praktisi pembelajaran dan peserta didik.

\section{Teknik Analisis Data}

Data yang diperoleh dari angket dianalisis secara deskriptif kualitatif dan kuantitatif. Data kualitatif berupa kritik dan saran dari ahli materi, ahli media, dan guru akuntansi yang dihimpun untuk memperbaiki Media Pembelajaran Akuntansi Berbasis Web Blog ini. Data kuantitatif yang dianalisis berasal dari:

a. Analisis Data Kuantitatif Penilaian Media

Mengacu pada konversi empat skala Djemari Mardapi (2008: 123) yaitu dengan cara menghitung rata-rata skor tiap indikator terlebih dahulu menggunakan rumus:

$$
\mathrm{X}=\frac{\sum x}{n}
$$

Keterangan:

$\mathrm{X}=$ skor rata-rata

$\sum \mathrm{X}=$ jumlah skor

$\mathrm{n}=$ jumlah penilai

b. Analisis Data Instrumen Angket Motivasi Belajar Siswa

Langkah-langkah yang digunakan untuk mengukur persentase motivasi siswa (Sugiyono, 2015: 135), yaitu:

1) Data kuantitatif skor angket motivasi siswa dianalisis.

2) Menjumlahkan skor untuk masingmasing aspek motivasi.

3) Menghitung skor dari motivasi siswa setiap aspek dengan rumus:

$\%$ skor motivasi belajar $=$

Skor motivasi belajar akuntansi skor maksimal

\section{HASIL PENELITIAN DAN PEMBA- HASAN}

Prosedur yang digunakan dalam pengembangan produk ini merupakan adaptasi dan dimodifikasi dari langkahlangkah penelitian dan pengembangan ADDIE. Penelitian meliputi lima tahap yaitu:

1. Tahap Analisis, berdasarkan wawancara siswa membutuhkan media yang interaktif dan variatif sesuai dengan materi pelajaran Menyusun Laporan Keuangan Perusahaan Dagang.

2. Tahap Perancangan meliputi perancangan desain produk yaitu 
peneliti menyusun storyboard yang terdiri dari menu home, video, fitur, kontak, materi, kuis dan download; menyusun materi, soal dan jawaban; dan mempersiapkan perangkat yang terdiri dari perangkat lunak XAMPP, Sublime Text, dan Windows 7.

3. Tahap Pengembangan meliputi pembuatan media; validasi meliputi:

a) Validasi ahli materi yang mendapatkan rata-rata skor 3,68 dengan kategori Sangat Baik.

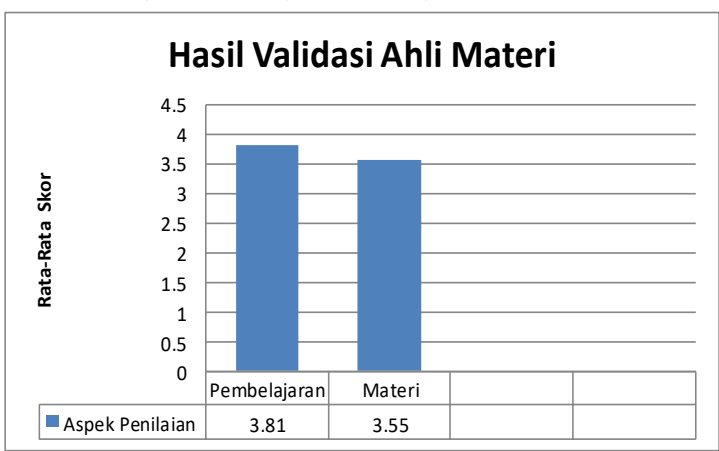

\section{Gambar 1. Diagram Batang Hasil} Validasi Ahli Materi

b) Validasi ahli media mendapat ratarata skor 2,97 dengan kategori Baik.

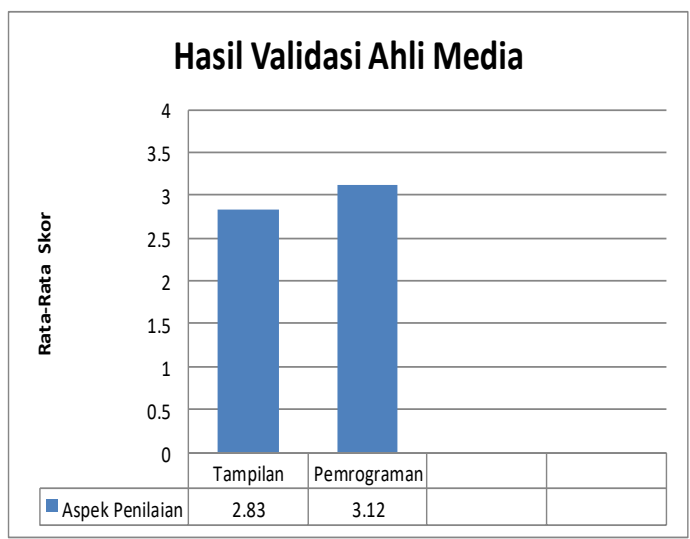

Gambar 2. Diagram Batang Hasil Validasi Ahli Media

c) Validasi guru akuntansi mendapat rata-rata skor 3,7 kategori Baik.

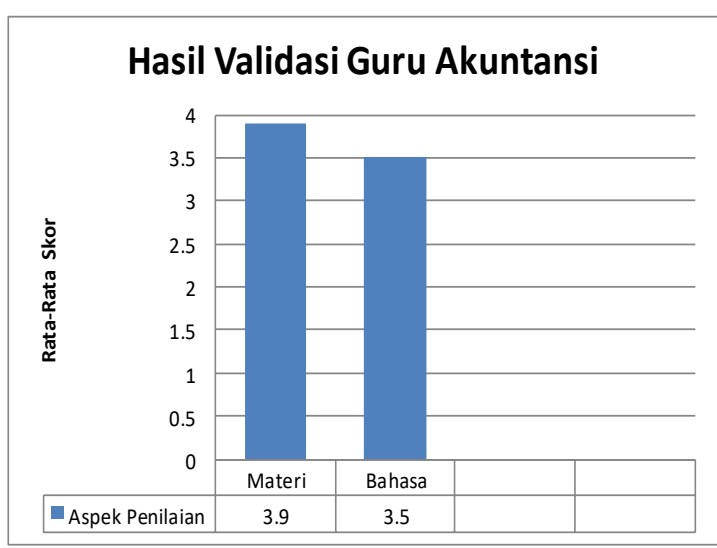

\section{Gambar 3. Diagram Batang Hasil} Validasi Guru Akuntansi

Tahap terakhir dari pengembangan yaitu revisi produk sesuai saran para ahli yaitu:

a) Revisi ahli materi yaitu ketidaksesuaian penanggalan antara bukti transaksi dengan yang di buku jurnal dan ketidaksesuaian nomor atau kode akun.

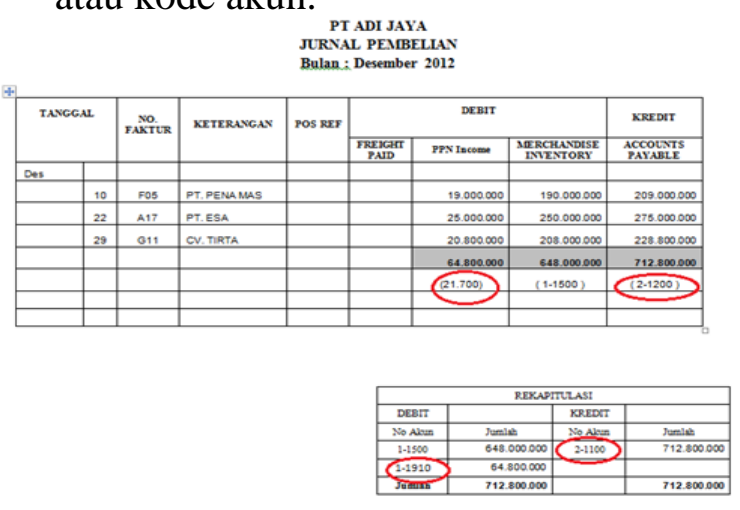

\section{Gambar 4. Nomor Akun Pada Jurnal Sebelum Revisi}



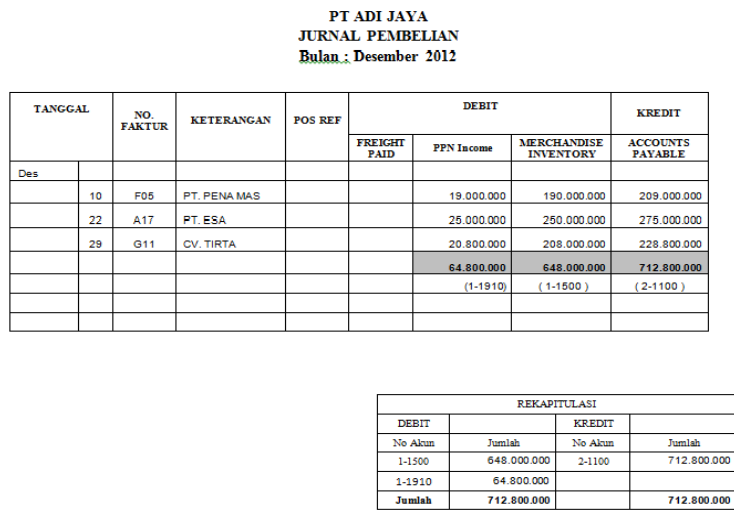

Gambar 5. Nomor Akun Pada Jurnal Setelah Revisi

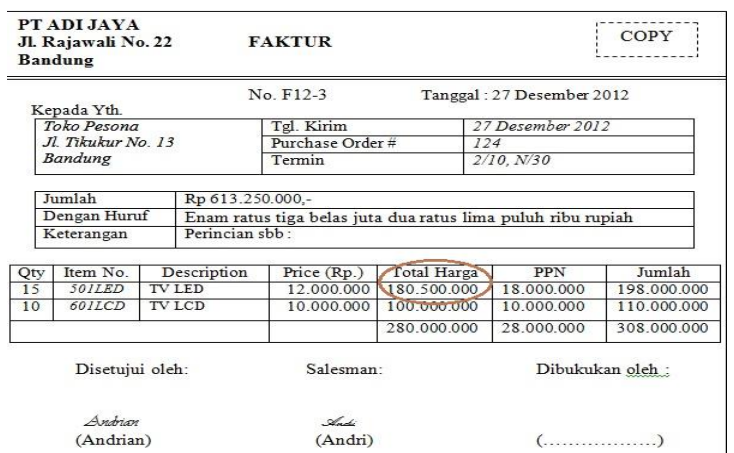

\section{Gambar 6. Nominal Angka Pada Bukti Transaksi Sebelum Revisi}

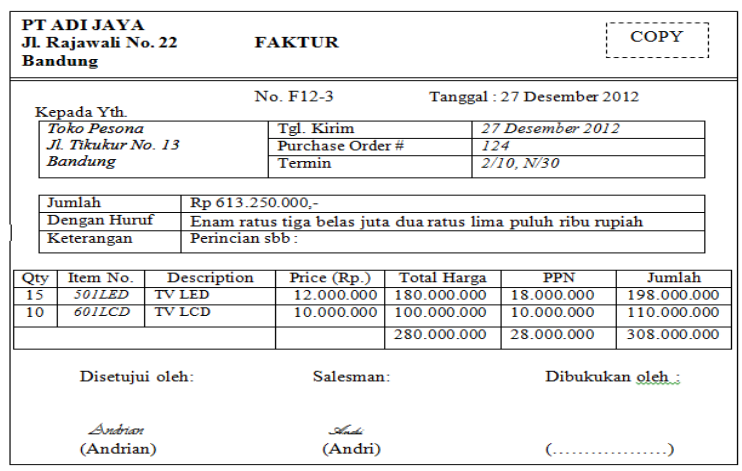

Gambar 7. Nominal Angka Pada Bukti Transaksi Setelah Revisi

b) Revisi ahli media yaitu penggunaan menu utama Bahasa Indonesia dan background diberi gambar yang berhubungan dengan Akuntansi.

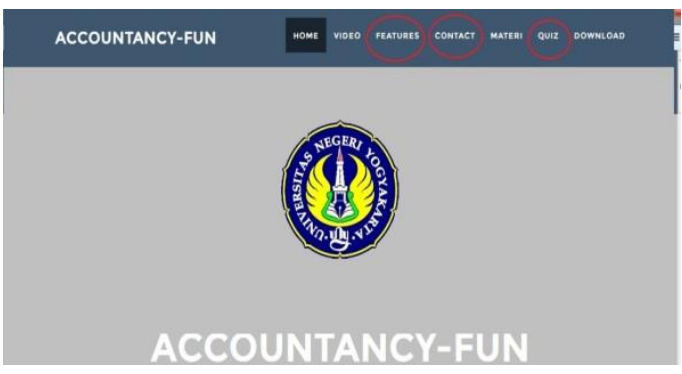

\section{Gambar 8. Menu Utama Sebelum Revisi}

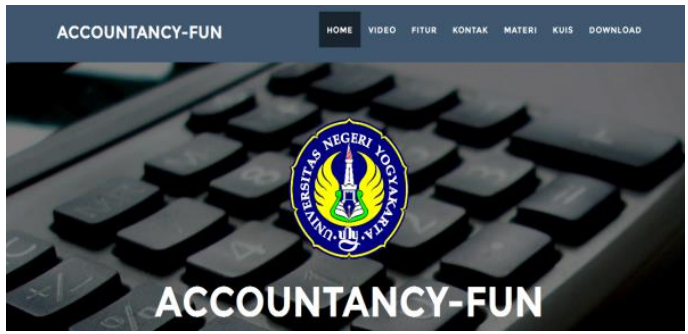

\section{Gambar 9. Menu Utama Sebelum Revisi}

c) Revisi guru akuntansi yaitu pada menu video, video yang diputar berjalan lamban atau terkadang not responding. Hal itu dipengaruhi oleh kecepatan akses jaringan internet yang digunakan

Setelah dilakukan revisi, didapatkan media pembelajaran akuntansi berbasis web blog yang sesuai dengan saran para ahli. Berikut ini adalah tampilan media pembelajaran akuntansi berbasis web blog setelah melewati tahap revisi dan siap diimplementasikan. 


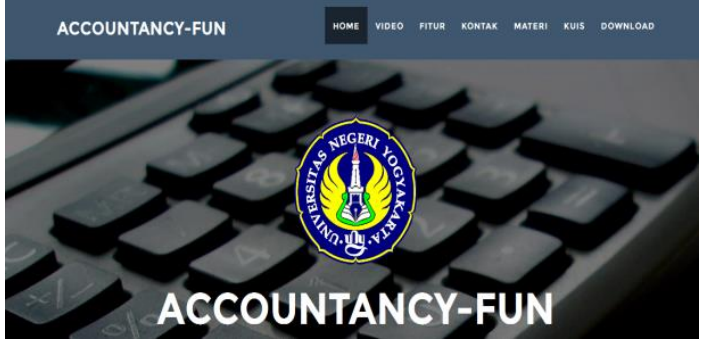

Gambar 10. Tampilan menu home

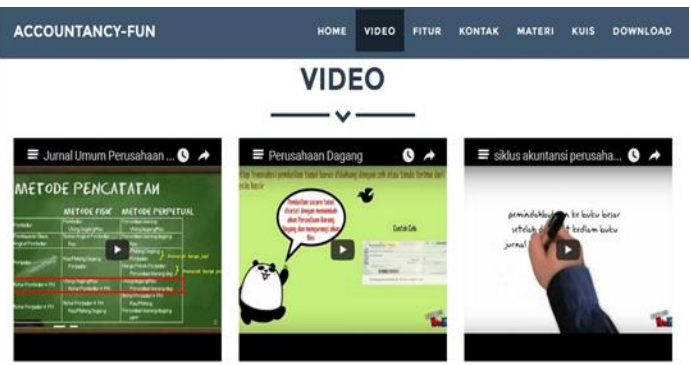

Gambar 11. Tampilan menu video

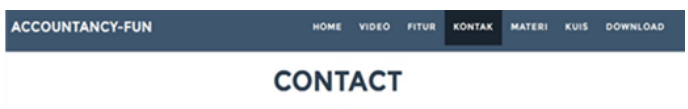

Gambar 12. Tampilan menu kontak

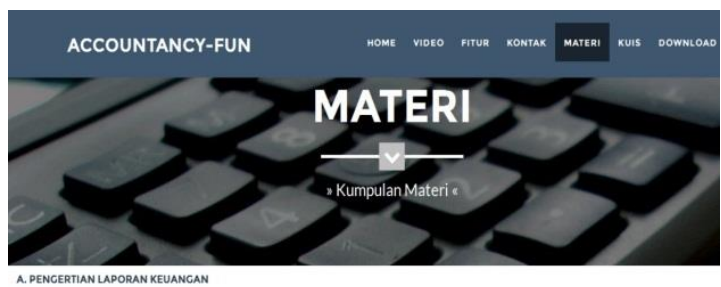

PENGERTIAN LAPORAN KEUANGAN PERUSAHAaN DACAN

Gambar 13. Tampilan menu materi

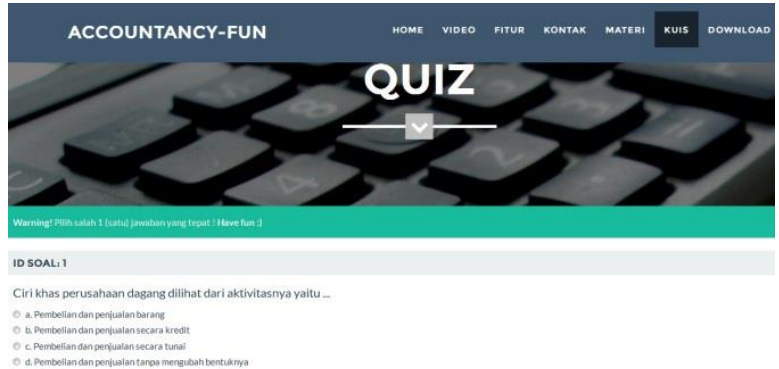

Gambar 14. Tampilan menu kuis

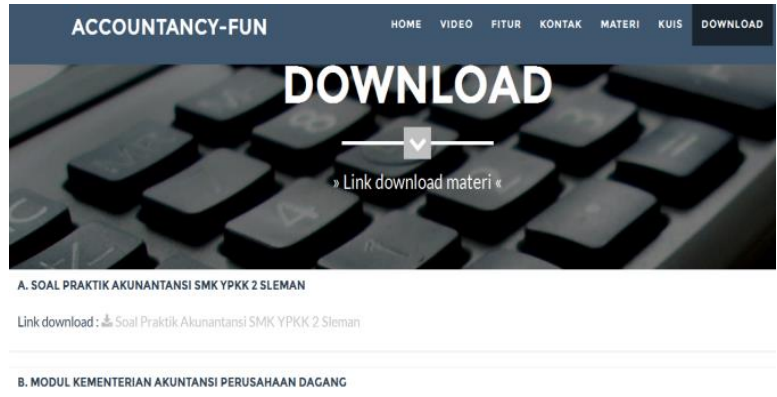

Gambar 15. Tampilan menu download

4. Tahap Implementasi

Tahap implementasi dilakukan pada kelas yang sesungguhnya dijadikan bahan penelitian. Uji coba lapangan dilakukan kepada 21 siswa kelas XI Akuntansi 4 SMK YPKK 2 Sleman. Siswa mengisi angket penilaian media pembelajaran akuntansi berbasis web blog. Berikut penilaian siswa terhadap media pembelajaran akuntansi berbasis web blog.

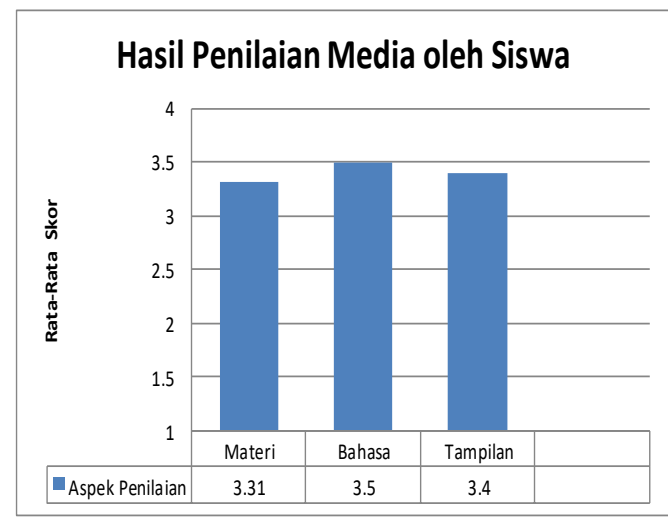

Gambar 16. Diagram Batang Hasil Penilaian Media oleh Siswa 
5. Tahap Evaluasi

Tahap evaluasi dilakukan menggunakan responden siswa uji coba lapangan. Peningkatan Motivasi Belajar siswa dilihat dari hasil pengukuran motivasi awal dan akhir melalui skala Likert. Berikut rekapitulasi skor motivasi belajar sebelum dan sesudah penggunaan media.

\section{Tabel 1. Rekapitulasi Angket Motivasi}

\begin{tabular}{|l|c|c|c|c|}
\hline \multicolumn{1}{|c|}{$\begin{array}{l}\text { Indikator } \\
\text { Motivasi } \\
\text { Belajar }\end{array}$} & \multicolumn{2}{|c|}{ Sebelum } & \multicolumn{2}{c|}{ Sesudah } \\
\cline { 2 - 5 } & $\mathbf{J m l}$ & $\mathbf{J m l}$ & $\mathbf{( \% )}$ \\
\hline $\begin{array}{l}\text { Tekun } \\
\text { Menghadapi } \\
\text { Tugas }\end{array}$ & 63 & 75 & 70 & 83,33 \\
\hline $\begin{array}{l}\text { Ulet } \\
\text { Menghadapi } \\
\text { Kesulitan }\end{array}$ & 74 & 88,09 & 76 & 90,47 \\
\hline $\begin{array}{l}\text { Memiliki } \\
\text { Minat } \\
\text { Terhadap } \\
\text { Berbagai } \\
\text { Soal }\end{array}$ & 115 & 68,45 & 137 & 81,54 \\
\hline $\begin{array}{l}\text { Lebih } \\
\text { Senang } \\
\text { Belajar } \\
\text { Mandiri }\end{array}$ & 107 & 63,69 & 119 & 70,83 \\
\hline $\begin{array}{l}\text { Cepat Bosan } \\
\text { Pada Tugas- } \\
\text { Tugas Rutin }\end{array}$ & 185 & 73,41 & 208 & 82,53 \\
\hline $\begin{array}{l}\text { Dapat } \\
\text { Mempertaha } \\
\text { nkan } \\
\text { Pendapat }\end{array}$ & 235 & 69,94 & 252 & 75 \\
\hline $\begin{array}{l}\text { Tidak Mudah } \\
\text { Melepaskan } \\
\text { Hal yang } \\
\text { Diyakini }\end{array}$ & 72 & 85,71 & 74 & 88,09 \\
\hline $\begin{array}{l}\text { Senang } \\
\text { Mencari dan } \\
\text { Memecahkan } \\
\text { Soal-Soal }\end{array}$ & 174 & 69,04 & 191 & 75,79 \\
\hline \multicolumn{1}{|c|}{ Jumlah } & $\mathbf{1 0 2 5}$ & $\mathbf{7 1 , 7 8}$ & $\mathbf{1 1 2 7}$ & $\mathbf{7 8 , 9 2}$ \\
\hline
\end{tabular}

Peningkatan terbesar terdapat pada indikator 3 sebesar 13,09\% yaitu indikator "Memiliki Minat Terhadap Berbagai Soal".
Urutan kedua ditempati oleh indikator 5 sebesar 9,12 \% yaitu indikator "Cepat Bosan Pada Tugas-Tugas Rutin”. Urutan ketiga ditempati oleh indikator 1 sebesar $8,33 \%$ yaitu indikator "Tekun Menghadapi Tugas". Urutan keempat ditempati oleh indikator 4 sebesar 7,14\% yaitu indikator "Lebih Senang Belajar Mandiri". Urutan kelima ditempati oleh indikator 8 sebesar $6,75 \%$ yaitu indikator "Senang Mencari dan Memecahkan Soal-Soal". Posisi tiga terbawah ditempati oleh indikator 6 "Dapat Mempertahankan Pendapat" sebesar 5,06 $\%$, indikator 2 yaitu "Ulet Menghadapi Kesulitan" sebesar 2,38\%, dan indikator 7 sebesar 2,38 \% yaitu "Tidak Mudah Melepaskan Hal yang Diyakini”.

Hipotesis yang diajukan pada uji beda ini terdiri dari hipotesis alternatif (Ha) yaitu pengembangan Media Pembelajaran Akuntansi Berbasis Web Blog sebagai media pembelajaran akan meningkatkan motivasi belajar Akuntansi, sehingga hipotesis nol $(\mathrm{H} 0)$ berbunyi pengembangan Media Pembelajaran Akuntansi Berbasis Web Blog sebagai media pembelajaran tidak akan meningkatkan motivasi belajar Akuntansi. Peneliti menggunakan uji t dua sampel ganda berpasangan (paired sample $t$ test). Berikut ini adalah total skor motivasi setiap siswa sebelum dan sesudah penggunaan Media Pembelajaran Akuntansi Berbasis Web Blog yang kemudian diuji t dua sampel antara skor total sebelum penggunaan media pembelajaran akuntansi berbasis web blog dan skor total setelah penggunaan media pembelajaran akuntansi berbasis web blog.

Tabel 2.Total Skor Motivasi Belajar Siswa

\begin{tabular}{|c|c|c|}
\hline No. & Sebelum & Sesudah \\
\hline 1 & 48 & 53 \\
\hline 2 & 57 & 63 \\
\hline 3 & 47 & 48 \\
\hline 4 & 46 & 48 \\
\hline 5 & 51 & 54 \\
\hline 6 & 43 & 45 \\
\hline 7 & 54 & 54 \\
\hline 8 & 55 & 59 \\
\hline
\end{tabular}




\begin{tabular}{|c|c|c|}
\hline 9 & 45 & 49 \\
\hline 10 & 49 & 61 \\
\hline 11 & 46 & 51 \\
\hline 12 & 46 & 52 \\
\hline 13 & 47 & 54 \\
\hline 14 & 45 & 55 \\
\hline 15 & 53 & 54 \\
\hline 16 & 55 & 60 \\
\hline 17 & 45 & 53 \\
\hline 18 & 43 & 52 \\
\hline 19 & 52 & 54 \\
\hline 20 & 53 & 57 \\
\hline 21 & 45 & 51 \\
\hline Total & 1025 & 1127 \\
\hline
\end{tabular}

Tabel 3. Hasil Rekapitulasi paired sample statistics

\begin{tabular}{|c|c|c|c|c|}
\hline \multicolumn{2}{|c|}{ Mean } & \multirow[b]{2}{*}{$\begin{array}{c}\text { Corr } \\
\text { e- } \\
\text { lation }\end{array}$} & \multirow[b]{2}{*}{$\mathbf{t}$} & \multirow{2}{*}{$\begin{array}{c}\text { Sig. } \\
(2- \\
\text { tailed } \\
)\end{array}$} \\
\hline Sebelum & Sesudah & & & \\
\hline 48.81 & 53.19 & .718 & $\begin{array}{c}5.88 \\
2\end{array}$ & 0,000 \\
\hline
\end{tabular}

Tabel paired sample statistics menunjukkan hasil perhitungan rata-rata skor total motivasi awal adalah sebesar 48,81 sedangkan motivasi akhir diperoleh skor 53,19. Tabel paired sample correlations menunjukkan bahwa korelasi antara dua variabel adalah 0,718 dengan sig 0,000. Artinya, korelasi antara skor total motivasi sebelum dan sesudah penggunaan media adalah kuat dan signifikan. Jika $\mathrm{t}$ hitung $\geq \mathrm{t}$ tabel maka hipotesis H0 ditolak, sebaliknya hipotesis Ha diterima.

Pada pengujian uji $\mathrm{t}$ diperoleh $\mathrm{t}$ hitung sebesar $-5,882$ dengan sig $(\mathrm{p})=0,000$. Karena $\mathrm{t}$ hitung $>\mathrm{t}$ tabel $(2,086)$ dan $\mathrm{p}<$ 0,05 menunjukkan bahwa H0 ditolak dan $\mathrm{Ha}$ diterima. Hal ini menunjukkan pengembangan Media Pembelajaran Akuntansi Berbasis Web Blog akan meningkatkan motivasi belajar Akuntansi. Media Pembelajaran Akuntansi Berbasis Web Blog mempengaruhi skor Motivasi Belajar Siswa.
Berdasarkan analisis yang tekah dilakukan, maka pembahasan dapat dijabarkan sebagai berikut yaitu prosedur penelitian dan pengembangan ini diadaptasi dari rangkuman aktivitas model ADDIE. Peneliti melakukan observasi dan analisis kurikulum serta analisis kebutuhan siswa. Peneliti mempersiapkan storyboard dan perangkat yang diperlukan. Mempersiapkan angket penilaian untuk para ahli dan angket penilaian oleh siswa serta angket motivasi belajar. Selanjutnya melakukan penilaian terhadap media pembelajaran akuntansi berbasis web blog dan merevisi sesuai saran para ahli. Tahap selanjutnya adalah mengukur keefektifan dari produk media pembelajaran akuntansi berbasis web blog yaitu dengan cara mengukur peningkaan motivasi belajar siswa sebelum dan sesudah penggunaan media pembelajaran akuntansi berbasis web blog.

Hasil penelitian pengembangan ini sesuai dengan teori yang dijelaskan oleh Hujair AH.Sanaky (2013: 42) yang mengatakan bahwa manfaat media pembelajaran salah satunya dapat menumbuhkan motivasi dalam belajar. Nana Sudjana dan Ahmad Rivai (2002: 24) juga mengemukakan manfaat media pembelajaran dalam proses belajar yaitu pembelajaran dengan memanfaatkan media pembelajaran akan lebih menarik perhatian siswa sehingga dapat menumbuhkan motivasi belajar pada siswa tersebut.

Gwen Solomon dan Lynne Schrum (2011: 16) mengungkapkan bahwa web blog sangat singkat dan memuat artikel yang hanya beberapa paragraf dengan gagasan yang jelas dan ringkas. Hal ini dikarenakan pembaca tidak ingin membaca artikel panjang dan bertele-tele pada monitor mereka, sehingga siswa dapat belajar bagaimana menyampaikan maksud yang diinginkan. Hal ini telah terbukti dengan penilaian pengembangan Media Pembelajaran Akuntansi Berbasis Web Blog oleh para Ahli maupun siswa termasuk dalam kategori Sangat Baik. 


\section{SIMPULAN DAN SARAN}

\section{Simpulan}

Berdasarkan hasil penelitian pengembangan dan pembahasan, dapat disimpulkan bahwa:

a. Pengembangan Media Pembelajaran Akuntansi Berbasis Web Blog melalui lima tahap yaitu analysis, design, development, impelementation, dan evaluation.

b. Tingkat kelayakan Media Pembelajaran Akuntansi Berbasis Web Blog diketahui berdasarkan penilaian dari Ahli Materi mendapat skor rata-rata 3,68 kategori Sangat Baik; penilaian dari Ahli Media mendapat skor rata-rata 2,97 kategori Baik; dan penilaian dari guru Akuntansi mendapat skor ratarata 3,7 kategori Sangat Baik.Serta penilaian oleh siswa kelas XI Akuntansi 4 terhadap Media Pembelajaran Akuntansi Berbasis Web Blog mendapat perolehan ratarata skor sebesar 3,36 kategori Sangat Baik.

c. Media Pembelajaran Akuntansi Berbasis Web Blog dapat meningkatkan Motivasi Belajar siswa sebesar 7,14\%. Motivasi Belajar Awal diperoleh skor 71,78\% sedangkan Motivasi Belajar Akhir sebesar $78,92 \%$.

\section{Saran}

Berdasarkan penelitian dan pengembangan (Research and Development) dan keterbatasan pengembangan seperti yang telah dijelaskan, Media Pembelajaran Akuntansi Berbasis Web Blog sebagai media pembelajaran masih memiliki banyak kelemahan. Oleh karena itu, beberapa saran pemanfaatan dan pengembangan produk lebih lanjut yang dibutuhkan adalah sebagai berikut:

a. Perlu melengkapi materi yang ada di dalam media pembelajaran web blog agar materi yang disampaikan kepada siswa lebih lengkap. b. Perlu menambahkan jumlah kuis yang lebih banyak pada media pembelajaran web blog agar siswa lebih tertantang dalam mengerjakan latihan soal.

c. Media pembelajaran web blog sebaiknya dapat diakses oleh siswa tidak hanya saat jam pelajaran Akuntansi saja, namun dapat diakses kapanpun dan dimanapun.

\section{DAFTAR PUSTAKA}

Djemari Mardapi. 2008. Teknik Penyusunan Instrumen Tes dan Non Tes. Yogyakarta: Mitra Cendekia Press.

Endang Mulyatiningsih. (2013). Metode Penelitian Terapan Bidang

Pendidikan. Bandung: Alfabeta.

Gwen Solomon dan Lynne Schrum.(2011).

WEB 2.0 Panduan bagi Para

Pendidik. Diterjemahkan oleh: Ririn Sjafriani. Jakarta: PT. Indeks.

Hujair Ah. Sanaky. (2013). Media Pembelajaran Interaktif-Inovatif. Yogyakarta: Kaukaba Dipantara.

Nana Sudjana dan Ahmad Rivai. (2002). Media Pengajaran. Bandung : Penerbit C.V.Sinar Baru

Sugiyono. (2015). Metode Penelitian Pendidikan Pendekatan Kuantitatif, Kualitatif dan RnD. Bandung: Alfabeta.

Wina Sanjaya. (2011). Strategi Pembelajaran Berorientasi Standar Proses Pendidikan. Jakarta: Kencana Prenada Media. 